\title{
The investigation of the ice field influence on the seismic prospecting works in the Arctic region *
}

\section{P.V. Stognii ${ }^{1}$}

${ }^{1}$ Educational Scientific and Experimental Center of Moscow Institute of Physics and Technology, Russian Federation

Different ice constructions, such as ice fields, ice ridges, icebergs, are of great interest for the research, for example, in the seismic prospecting works. Ice constructions, especially ice fields, bring in lots of extra reflections into the seismograms, which are very difficult to differ from the reflections, coming from the hydrocarbon deposits, which are of great importance for the geologists. For the decrease of the influence of the reflections from the ice field, the seismic source of impulse is often established deep into the ice cover, approaching the contact border between the ice and the water layer. In this work, the results of mathematical modelling of the seismic waves spread through the geological layers of the Arctic region with the help of the grid-characteristic method are presented. The analysis of influence of establishing the source of impulse on the border between ice and water on the decrease of the seismic wave velocities, on the wave fields is carried out. The model with the seismic source of impulse, located on the contact border between ice and water, makes worse the final result, while the model with the source of impulse on the surface of ice demonstrates a decrease of the seismic wave velocities.

Keywords: ice fields; ice ridges; icebergs, Arctic region; seismic source of impulse; gridcharacteristic method.

Introduction. Today the Arctic region is one of the most important regions for the Russian Federation as large hydrocarbon deposits are located there [1]. Such gas fields as Murmanskoe, Ledovoe fields are among the largest hydrocarbon fields of the Arctic shelf. Each of the fields contains more than $100 \mathrm{mlrd} . \mathrm{m}^{3}$ of gas.

The hard climate conditions and the presence of a great amount of ice constructions, such as icebergs, ice ridges, ice fields, make the process of conducting the seismic works very difficult. The ice constructions bring in extra reflections into the seismograms, the result of the seismic works [2]. These reflections are difficult to distinguish from the seismic waves, reflected from the other geological layers, water, soil layers, gas deposits [3].

The ice field brings in lots of reflections into the seismograms as a result of the multiple wave reflections between the contact borders of ice-water and ice-air. There is the specific way for the decrease of these multiple waves, which is used during the real seismic works on the investigated territories with the ice field on the surface. The ice field is the slice of ice with the height up to $3 \mathrm{~m}$. Then, the geologists construct a cavity, where they establish the seismic source of impulse and the

\footnotetext{
*E-mail: stognii@phystech.edu.
} 
receivers of the reflected waves. This way of establishing the system of source-receivers inside the cavity is supposed to stop the spread of the seismic waves spread along the ice surface.

In this work the results of the mathematical modelling of the seismic waves spread through the geological media with the ice field on the surface are presented. The influence of deepening the system source-receivers on the result wave fields is investigated. The main equations, describing the behavior of the seismic waves in the linear-elastic medium, are described. Then, the description of the grid-characteristic method, used in all the computations, is presented. The analysis of the wave fields with the deepened system source-receivers and with the system source-receivers on the surface of ice is carried out.

Mathematical model. For describing the dynamic behavior of the seismic waves, the system for the linear-elastic medium was used [4]:

$$
\begin{gathered}
\rho \frac{\partial}{\partial t} v=(\nabla \cdot \sigma)^{T} \\
\frac{\partial}{\partial t} \sigma=\lambda(\nabla \cdot v) I+\mu\left(\nabla \times v+(\nabla \times v)^{T}\right)
\end{gathered}
$$

In the equations (1), (2) $\rho$ is the medium density, $v$ is the seismic velocity, $\sigma$ is the Caushy stress tensor, $\mathrm{t}$ is the time, $\lambda, \mu$ are the Lame parameters, characterizing the properties of the elastic medium.

Numerical method. For solving the system of equations (1), (2) numerically, the gridcharacteristic method was used [5, 6]. For this, the system of equations (1), (2) is rewritten as:

$$
\frac{\partial \mathbf{q}}{\partial t}+\mathbf{A}_{x} \frac{\partial \mathbf{q}}{\partial x}+\mathbf{A}_{y} \frac{\partial \mathbf{q}}{\partial y}=0
$$

In (3) the vector q consists of three components of the Caushy stress tensor and two components of the velocity: $\mathbf{q}=\left\{\sigma_{x x}, \sigma_{x y}, \sigma_{y y}, v_{x}, v_{y}\right\}$. The matrixes $\mathbf{A}_{x}, \mathbf{A}_{y}$ are constructed out of the coefficients of the system of equations (1), (2).

Then, the equation (3) is split into the coordinates and turns into two 1D systems of equations:

$$
\frac{\partial \mathbf{q}}{\partial t}+\mathbf{A}_{x} \frac{\partial \mathbf{q}}{\partial x}=0
$$

Now, the system (4) is examined only for the coordinate $\mathrm{x}$. The system (4) is hyperbolic, then it can be rewritten as:

$$
\frac{\partial \mathbf{q}}{\partial t}+\boldsymbol{\Omega}_{x} \boldsymbol{\Lambda}_{x} \boldsymbol{\Omega}_{x}^{-1} \frac{\partial \mathbf{q}}{\partial x}=0
$$

where the matrix $\boldsymbol{\Omega}_{x}$ is constructed out of the eigen vectors of the matrix $\mathbf{A}_{x}$. The matrix $\boldsymbol{\Lambda}_{x}$ is constructed out of the eigen values of the matrix $\mathbf{A}_{x}$. The eigen values of the matrix $\mathbf{A}_{x}$ are equal to $\left\{-c_{p}, c_{p},-c_{s}, c_{s}, 0\right\}$, where $c_{p}, c_{s}$ can be found from $c_{p}=\sqrt{(\lambda+2 \mu) / \rho}, c_{s}=\sqrt{\mu / \rho}$. After the variable change $\mathbf{p}=\boldsymbol{\Omega}_{x}^{-1} \mathbf{q}$, the system (5) will transfer to:

$$
\frac{\partial \mathbf{p}}{\partial t}+\boldsymbol{\Lambda}_{x} \frac{\partial \mathbf{p}}{\partial x}=0
$$


The Rusanov scheme of the $3^{\text {rd }}$ order of accuracy was applied for solving the system (6), which consists of five independent equations [7].

For calculating the points on the borders of the models, the following border conditions were established. The free boundary condition was established on the upper border. The non-reflecting boundary condition was used on the side and lower borders of the models.

Results. The spread of the seismic waves in the ice field was modelled for the 3D case. The model consisted of two layers: the water layer and the ice field on the surface. The ice density was equal to $917 \mathrm{~kg} / \mathrm{m}^{3}$, the water density was $1000 \mathrm{~kg} / \mathrm{m}^{3}$. The longitudinal sound velocity in water was $1500 \mathrm{~m} / \mathrm{s}$, the longitudinal sound velocity in ice was $3940 \mathrm{~m} / \mathrm{s}$. The transverse sound velocity in the ice field was $2493 \mathrm{~m} / \mathrm{s}$. The water depth was $100 \mathrm{~m}$, the ice depth was $3 \mathrm{~m}$. The overall area was $4 \times 10^{4} \mathrm{~m}^{2}$. The coordinate step was equal to $0.2 \mathrm{~m}$. The time step was $10^{-5} \mathrm{~s}$.

The seismic source of the Reiker impulse with the central frequency of $30 \mathrm{~Hz}$ was used for modelling the initial impulse. The seismic receivers in number of 100 were located in the center of the modelling area at distance of $1 \mathrm{~m}$ from each other. The calculations of two cases of the system source-receivers were carried out. In the first case, the system source-receivers was situated on the surface of the ice field. In the second case, the system source-receivers was situated on the contact border between the water layer and the ice field.

The spread of the seismic waves from the impulse source was modelled during $150 \mathrm{msec}$. The graphs in fig. 1, 2 depict the wave fields for the model with the system source-receivers, located on the surface of the ice field (fig. 1) and for the model with the system source-receivers, located on the contact border between the ice field and the water layer (fig. 2). It follows from fig.1, 2 that the seismic signal possesses a more expressive form in case of its location on the surface of the ice field, fig. 1 . In addition, the multiple waves are properly distinguished for the case, when with the system source-receivers is located on the surface of the ice field. If we examine the model, where with the system source-receivers is situated on the contact between water and ice, the waves in the ice layer, obtained as a result of reflecting from the border ice-air and the border ice-water, are hardly identified.

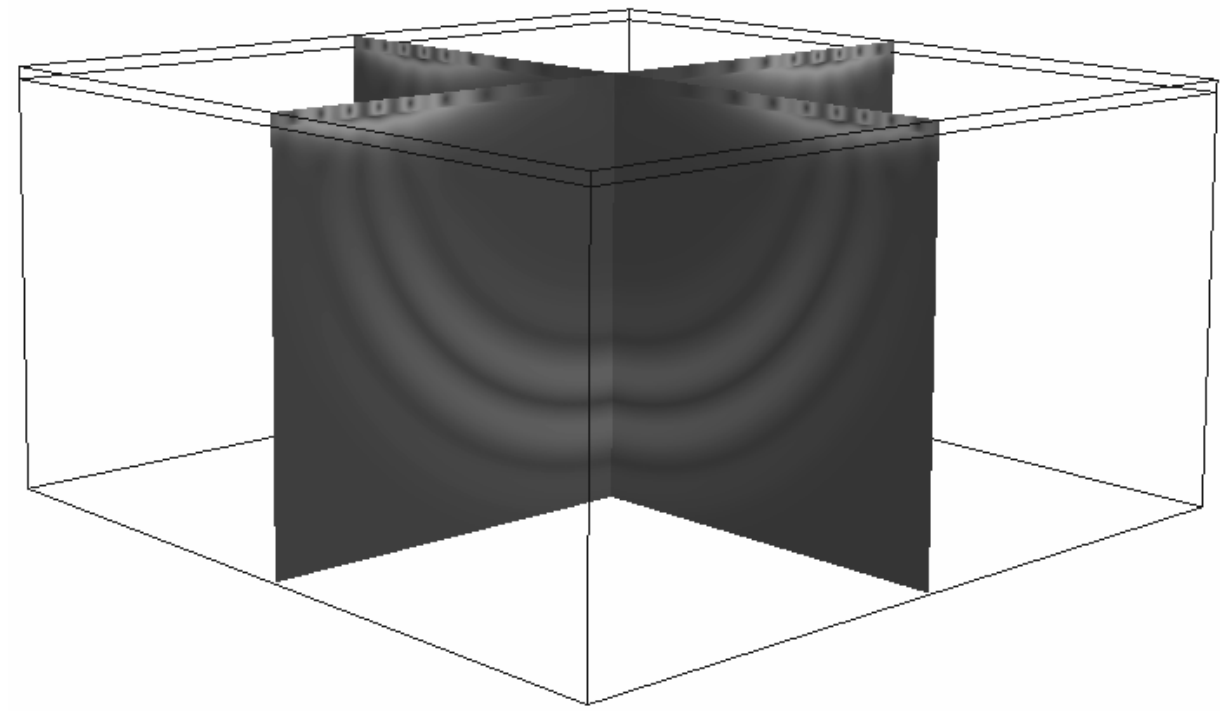

Fig. 1. The wave field for the model with the ice field when the system of the source of impulse and the receivers is located on the surface of ice. 


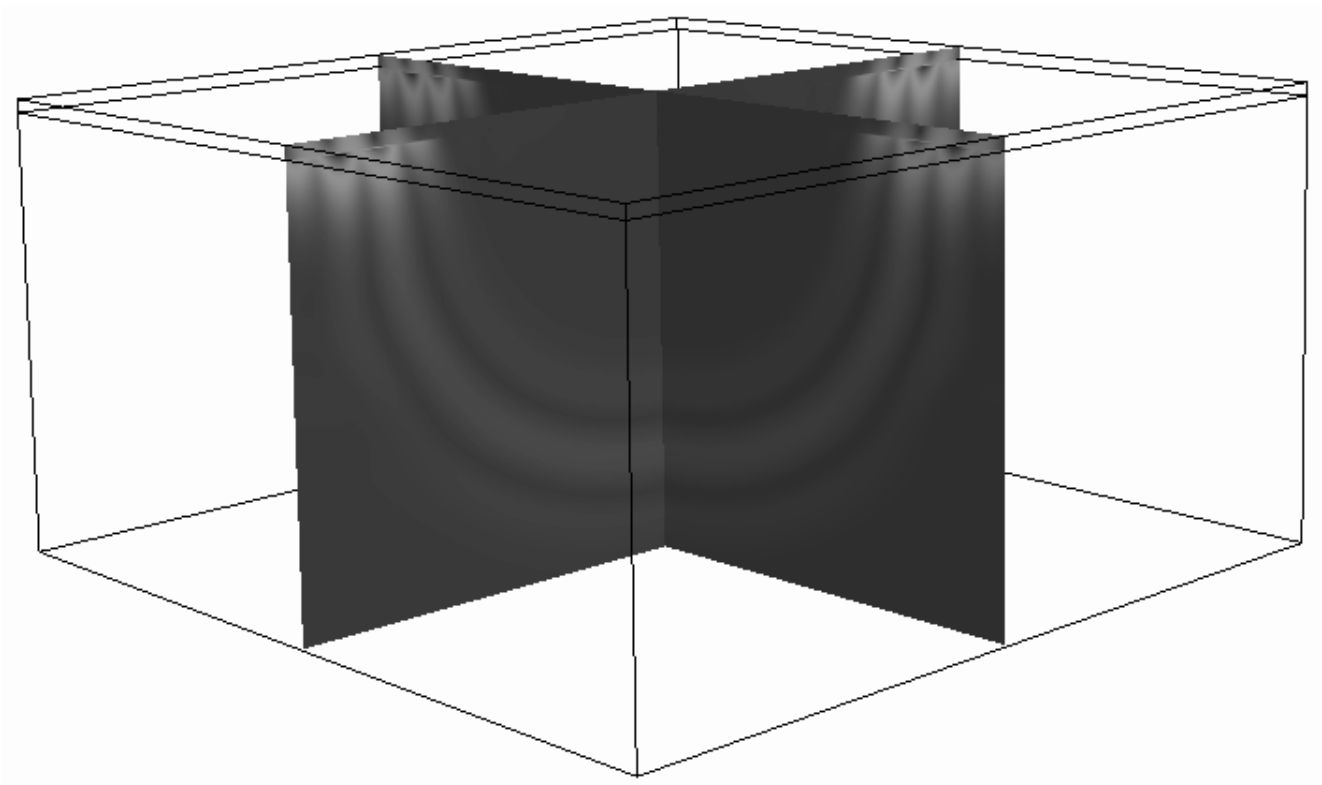

Fig. 2. The wave field for the model with the ice field when the system of the source of impulse and the receivers is located on the contact border ice-water.

Conclusion. In this work the results of the numerical modelling of the seismic waves spread in 3D models with the ice field were presented. The mathematical model was described in detail. The system of the main equations, describing the dynamic behavior of the seismic waves in the media, were described. The grid-characteristic method of the third order of accuracy, used in all the computations, was described.

The results of influence of establishing the system of the source of impulse and the receivers, on the surface of the ice field and on the contact border between the ice layer and water layer, on the wave fields were obtained. The wave fields showed the better results for the case, when the system of the source of impulse and the receivers was established on the surface of the ice field.

\section{References}

1. Petrov, Igor. Problems of simulation of natural and anthropogenous processes in the Arctic zone of the Russian Federation. Matem. Mod. 30(7): 103-136, 2018.

2. Epifanov, Viktor. The Effect of Stress Pulses on the Structure of Ice in an Intermediate Layer. Doklady Physics 63(4): 150-154, 2018.

3. Stognii P. V., Khokhlov N. I. 2D Seismic Prospecting of Gas Pockets // Smart Innovation, Systems and Technologies. - 2019. - Vol. 133. - P. 156-166. — DOI: 10.1007/9783-030-06228-6_14

4. Novatckiy V. Teoriya uprugosti [Theory of elasticity]. Moscow: Mir, 1975. P. 872 (in Russian).

5. Muratov M.V., Petrov I.B. Application of mathematical fracture models to simulation of exploration seismology problems by the grid-characteristic method // Computer Research and Modeling, vol. 11, no. 6, pp. 1077-1082, 2019.

6. Khokhlov, N.; Stognii, P. Novel Approach to Modeling the Seismic Waves in the Areas with Complex Fractured Geological Structures. Minerals 2020, 10, 122, 2020. 
7. Rusanov V. V. Raznostnye shemy tret'ego poryadka tochnosti dlya skvoznogo scheta razryvnyh resheniy [Differential schemes of third order of accuracy for transparent computations of discontinuous problems] // Dokl. AAN USSR. 1968. Vol. 9, No. 4. P. 85-97 (in Russian).

\section{Author:}

Polina V. Stogniy, Junior Researcher, Laboratory of Applied Computational Geophysics, Moscow Institute of Physics and Technology (Russian Federation, Dolgoprudny, Institutsky per., 9), 8 (916) 25883 87, stognii@phystech.edu 
УДК 519.6, 004.93'1

$10.23947 / 2587-8999-2020-1-1-31-36$

\section{Исследование влияния ледового поля на сейсморазведочные работы в Арктике *}

\section{П.В. Стогний}

Московский физико-технический институт, Долгопрудный, Российская Федерация

Различные ледовые конструкции, такие как ледяные поля, ледяные хребты, айсберги, представляют большой интерес для исследований в сейсморазведочных работах. Ледяные поля, вносят дополнительные отражения в сейсмограммы, которые трудно отличить от отражений, поступающих от месторождений углеводородов, имеющих большое значение для геологов. Для уменьшения влияния отражений от ледяного поля сейсмический источник импульса часто устанавливается глубоко в ледяном покрове, приближаясь к границе контакта льда и слоя воды. В данной работе представлены результаты математического моделирования распространения сейсмических волн в геологических слоях Арктики с помощью сеточнохарактеристического метода. Проведен анализ влияния установления источника импульса на границе между льдом и водой на снижение скоростей сейсмических волн, на волновые поля. Модель с источником сейсмического импульса, расположенным на границе контакта между льдом и водой, дает худший конечный результат, в то время как модель с источником импульса на поверхности льда демонстрирует уменьшение скоростей сейсмических волн.

Ключевые слова: ледяные поля; ледяные гряды; айсберги, арктический регион; сейсмический источник импульса; сеточно-характеристический метод.

\section{Aвтор:}

Стогний Полина Владимировна, Младший научный сотрудник лаборатории прикладной вычислительной геофизики, Московский физико-технический институт (Научноисследовательский университет) (РФ, г. Долгопрудный, Институтский пер., 9), 8(916)258 83 87, stognii@phystech.edu

\footnotetext{
*E-mail: stognii@phystech.edu.
} 